\title{
The Impact of Corona Virus Disease 2019 (COVID-19) on Indonesia Property Stock Index
}

\author{
Kevin Ronaldo Gotama ${ }^{1}$, Njo Anastasia ${ }^{2 *}$ \\ ${ }^{1}$ Faculty of Civil Engineering, Petra Christian University \\ ${ }^{2}$ Faculty of Business and Economics, Petra Christian University \\ Jl. Siwalankerto 121-131, Surabaya 60236, Indonesia \\ *Corresponding author, Email: ${ }^{1}$ gotama.kevin@gmail.com; ${ }^{2 *}$ anas@ @etra.ac.id
}

\begin{abstract}
A promising investment in the property sector is due to appreciation in property value. As an economic instrument, the stock market, inseparable from different environmental factors, was triggered by incident in Wuhan, Hubei Province, China, an outbreak of acute respiratory tract infection 2 (SARS-CoV-2) in December 2019 and then spread across China. This study is a comparative study on the stock index of the property sector on the stock exchange of countries affected by the Corona Virus Disease 2019 (COVID-19) case, with a purposive sampling technique according to certain criteria for sample selection. The event analysis was performed by analyzing market reaction; with COVID-19 incident effect as one of the event tests, the stock price index. The findings of the study indicate that there is an index response to the incident of COVID-19. The reflected reaction shows in the abnormal return and trade volume activity before and after the incident. Thus, this study is expected to be taken into consideration for stock investors regarding the impact of the Corona Virus Disease 2019 (COVID-19) pandemic on stock prices, by providing an overview of changes in stock prices during the monitoring period, so that they can make investment decisions in the period before and after incident.
\end{abstract}

Keywords: Event Study; COVID-19; Abnormal Return; Trading Volume Activity.

\section{Introduction}

Investments in the property sector are deemed as investments with opportunities and gains as the property sector is believed to be growing by the year. Moreover, the property sector is regarded as one of the most important sectors in Indonesia by which investors are drawn. It is also an important indicator to analyze the economic health of a nation. The capital market plays an important role in economic activities. In countries where the market economy system is at play, the capital market has been a driving force of economic growth. Although it is not directly related to the dynamics of the capital market, its effects in a non-economic environment are also felt on the activities in the capital market. While the non-economic environmental factors are not specifically linked to capital market dynamics, this does not rule out the possibility that they have an impact on the capital market activities. Natural disasters, conflicts, protests, and political and legal problems are often the primary causes of stock market price volatility around the world. As can be seen right now, non-macroeconomic events affect the capital market. Previous studies show that the reaction of the capital market is affected by non-macroeconomic information, such as the Avian Flu pandemic and Severe Acute
Respiratory Syndrome (SARS) pandemic in Asian countries (Chen, Jang, \& Kim, 2007), the Ebola outbreak (Ichev \& Marinc, 2018), the Iraqi war in 2003 (Guidolin \& Ferrara, 2010), terrorist attacks (Chen \& Siems, 2004) and the latest pandemic in 2020 which is the Corona Virus Disease 2019 (COVID-19), otherwise known as the coronavirus.

In December 2019, the plague of coronavirus 2 (SARSCoV-2) infection, or the acute respiratory infection occurred in Wuhan, Hubei Province, China, and spread throughout the nation. The global economic effect caused by the Corona Virus Disease 2019 (COVID-19) showed a decline in demand, meaning that there is no consumer purchasing goods and services. The pandemic caused a serious harm in the economic activities of countries around the world, but to assess the extent of the actual impact is challenging to say the least. More than 100 countries had already instituted lockdowns, whether full or partial, and both air and intercity travel was down by 70 to 90 percent by the end of March 2020 compared to the previous year (Dunford, et al., 2020). The Corona Virus Disease 2019 (COVID-19) causes unprecedented damages to the economy of countries than other natural and human-made crises like climate change, nuclear wars, natural disasters, and local 
tragedies (Goodell, 2020). Moreover, during this outbreak, COVID-19 caused global stock markets to crash; the Dow Jones index experienced the largest drop of 3000 points on March 16, 2020, breaking the previous record of 2,300 points set four days earlier on March 12, 2020 (Duffin, 2020).

The market reaction towards an event or published information, the event of Corona Virus Disease 2019 (COVID-19) towards stock index price is also an event study. Studies that use event study by Chen, Jang, \& Kim (2007) discusses the effect of the SARS pandemic on the price of hotel industry stocks in Taiwan. Meanwhile, Ichev \& Marinc (2018) studies the effect of the Ebola plague on stock return on companies listed on the New York Stock Exchange (NYSE) and NASDAQ Composite. Both studies mentioned have not discussed the relation between property sector stocks and the latest Corona Virus Disease 2019 (COVID-19) pandemic, which makes an interesting basis to be studied further. This study aims to understand the market's reaction which is reflected by the significant difference between abnormal return and trading volume activity in the periods before and after the announcement of Corona Virus Disease 2019 (COVID-19) as a pandemic by the World Health Organization (WHO). This study is expected to be a point of consideration for stock investors on the effect of the Corona Virus Disease 2019 (COVID-19) pandemic on stock prices, by giving them a picture of the change in stock prices during the monitoring period, so that they can make investment decisions in periods before and after the event. Said picture will be a track record of the event, which is the Corona Virus Disease 2019 (COVID-19) pandemic that affects the stock market. The object of study is the property stock index in Indonesia's stock exchange (IDX Property) as well as four of the best-performing countries for property investments according to AFIRE (Association of Foreign Investor in Real Estate) namely the United States (S\&P 500 Real Estate), Brazil (Bovespa Real Estate), China (SZSE Real Estate), and the United Kingdom (FTSE 350 Real Estate).

\section{Literature Review}

\subsection{Capital Market, Stocks, and Return}

The stock market, in general, is a structured financial system that includes commercial banks, all financial intermediary institutions, and all marketable securities in circulation. In its most basic form, the capital market is a market (a physical location) set up to exchange stocks, bonds, and other forms of securities with the use of a stock broker (Sunariyah, 2011). Formally, the capital market can be defined as a market for various long-term financial instruments (security) that can be traded, whether it's in the form of loans or personal capital, issued by the government, public authorities, or private companies (Husnan, 2005).

Stocks are a piece of paper that indicates the investor's rights, i.e., the party that owns the paper, to acquire a share of the organization's prospects or properties, as well as various conditions that enable the investor to exercise his rights (Husnan, 2005). Stocks are one of the most popular instruments of the capital market. Stocks are valuable securities that represent an individual's or an instance's ownership of a certain company. There are two advantages from Investor's perspective in having stocks, which are dividends and capital gain. Dividends are the sharing of the profit that was made by the company that issued the stocks. Capital gain is the difference between the buy price and the sell price of the stocks in other words capital gain is buy price below sell price. A stock price index is a certain value of the combination of several stock prices. Composite price index is an indicator of the performance of stocks in the market (Tandelilin, 2010). As a result, the sectoral stock price index can be described as a stock price index that includes all listed companies in each sector.

Return is the income stated in percentage from the initial capital investment. Investment income from stocks is the result acquired from stock trading, where a positive is called capital gain, and a negative is called capital loss (Samsul, 2006). In reality, oftentimes the return acquired or expected is not what was initially expected. Usually, there are differences between the return expected and accepted, which is called abnormal return, defined as the difference between expected return and actual return.

1. Actual return is the return calculated from the difference in current stock prices and yesterday's stock prices, divided by yesterday's stock prices,

2. Return market is market portfolio income which is acquired if all stocks in the market are held in the same proportion.

3. Expected return is the return expected by investors in the upcoming future.

4. Abnormal return is the excess of actual return compared to normal (expected) return. 
Trading Volume Activity is the sum of stocks or contracts traded between a certain period of time, also considered as the measurement of the strength and weakness of the market (Salim, 2003). Trading volume activity is an instrument that can be used to monitor the reaction of the capital market towards information through the parameter of trade volume activity in the capital market. With this approach, the trade volume in the market can be monitored and assessed, as a reflection of investors' behavior in dealing with certain information which is circulating in the market (Setyawan, 2000).

\subsection{Efficient Market Theory}

The Efficient Market Theory is closely related to information. Currently circulating information can cause both a positive or negative reaction. Positive if it can increase stock prices in the market, and negative if the opposite happens. According to Fama (1970), the Efficient Market Theory is divided into three parts according to the strength of existing data, namely:

1. Weak form efficient market, states that the price that forms on a stock is a reflection of past movements of said stock.

2. Semi-strong form efficient market, states that a stock's price reflects every relevant public information, and the price that forms on a stock is a reflection of an information on the market, such as financial statement and additional information. The concept of this form is that once the information becomes public, and spreads across the market, all investors will respond automatically causing the stock price to represent all of the information.

3. Strong form efficient market, states that a stock's price reflects every bit of information, both public and private information. The strong type in this case involves all relevant historical information, as well as information available to the general public and information only identified by a few parties, such as company executives, boards of directors, and creditors.

According to Tandelilin (2010), in order to achieve the following competitive sector, a number of requirements must be met. (1) Many investors are fair and want to maximize their profits. By reviewing, valuing, and exchanging securities, these investors are actively engaged in the market. Furthermore, investors are price takers, which means that one investor's activities would have no impact on the price of a safe, (2) Both market participants may obtain information at the same time in a simple and inexpensive manner, (3) The information that appears is completely random, and (4) Investors respond rapidly to new information, causing the price of a security to fluctuate in response to changes in real value as a result of that information.

Moreover, it can also be used to measure the impact of both economic and non-economic (social politic) events. The aim of testing the information content is to see how an announcement will be received. If the announcement contains details, it is anticipated that the market will respond when it receives the announcement. A change in the price of the protection in question indicates market reaction. There are three reasons to perform event studies, which are as follows: (1) Event studies are commonly used to investigate the impact of an event on a company's value, (2) Since stock prices are available at the time of the event, event analyses specifically calculate the impact of events on the company's stock price at the time of the event, and (3) The event analysis contains data that is simple to access, allowing for studies to be conducted. Data on the share prices of the business in question and the market index are commonly used to perform case study analysis.

Event study consists of window period, which is the period in which the event itself and the consequences happened, and estimation period to estimate the expected return. Through the window period, the event and the consequences can be observed. The duration of the window period has to be as narrow as possible, but just enough so that the event and its consequences can be captured. The estimation period is used to forecast the expected return in the event period. For studies that use daily data, several studies suggested 30 days as it is the minimum sample to qualify for the normality assumption, in line with the central limit theorem concept (Hartono, 2015). Previous studies showed the effect of the capital market towards the Corona Virus Disease 2019 (COVID-19) on the five largest stock indexes in Asia (AlAli, 2020), with varying window period and estimate period of 250 , resulting in significant differences in window periods of $(-5,5),(-15,15),(-30,30)$ and $(-60,60)$ before and after the event date.

World Health Organization (WHO) explained that Coronaviruses (Cov) are viruses that infect the respiratory system. This Coronavirus causes symptoms ranging from regular flu to 
severe ones such as the Middle-Eastern Respiratory Syndrome (MERS-CoV) and Severe Acute Respiratory Syndrome (SARS-CoV). The Coronavirus is zoonotic, meaning it transmits between animals and humans. Based on Indonesia's Ministry of Health, the Corona Virus Disease 2019 (COVID-19) started in Wuhan on December 30, 2019, and rapidly spread to other countries. This affected the economic condition of many countries from the trading, investment, and tourism standpoint, including Indonesia.

The development of the economy and investment which have been explained above showed that information received can be labeled as good news or bad news, depending on the market's reaction towards said information. If the market gives a positive reaction, then it can be labeled as good news, and vice versa. A similar study was conducted by Chen, Jang, \& Kim (2007) when the SARS pandemic hit, and the results showed that the capital market in Taiwan responded to the pandemic with a significant cumulative abnormal return before and after the event. As well as an event study regarding the Ebola plague which showed a negative result on the return in the New York Stock Exchange (NYSE) and NASDAQ Composite listed companies (Ichev \& Marinc, 2018). Furthermore, the study of AlAli (2020) which focused on the effect of Corona Virus Disease 2019 (COVID-19) pandemic on companies listed in China, the United States, the United Kingdom, Italy, Spain, France, German, Swiss, and South Korea stated that information and semi-strong market efficiency proves that there is a significant difference on the stock index during the Corona Virus Disease 2019 (COVID-19) event, which is a negative effect along with a significant difference on abnormal return index. The study of Kandil Goker, Eren, \& Karaca (2020) which focused on the impact of Corona Virus Disease 2019 (COVID-19) on The Borsa Istanbul Sector Index proves that tourism sector on Istanbul stock index is the most affected sector by Corona Virus Disease 2019 (COVID-19). The study of Bash (2020) strengthened the Corona Virus Disease 2019 (COVID-19) case on the stock index of 30 countries, with the most position on April 20, 2020, which showed the stock index reacting negatively towards Corona Virus Disease 2019 (COVID-19). The varying window period and estimate period of -250 of the study showed a result of a significant difference before and after the event in all window periods except $(-1,1)$ and $(-3,3)$.
$\mathrm{H}_{1}$ : There is a significant difference in abnormal return of stocks in property in the announcement of the Corona Virus Disease 2019 (COVID-19) as a pandemic from World Health Organization (WHO)

$\mathrm{H}_{2}$ : There is a significant trading volume activity difference of stocks in property in the announcement of the Corona Virus Disease 2019 (COVID-19) as a pandemic from World Health Organization (WHO)

\section{Methods}

This study is a comparative study with the population of the stock index of the property sector on the stock exchange of countries affected by the Corona Virus Disease 2019 (COVID-19) case. Purposive sampling was used in the sample selection process. A method of deciding the population to be sampled based on such parameters is known as a purposeful sampling method. This research's sample are property sector companies listed on the Indonesian Stock Exchange (IDX Property) and the top four countries for property investment according to AFIRE (Association of Foreign Investor in Real Estate) namely the United States (S\&P 500 Real Estate), Brazil (Bovespa Real Estate), China (S\&P 500 Real Estate) and the United Kingdom (FTSE 350 Real Estate). Secondary data is the form of data used in this research, collected in the form of the historical closing price and trading volume through www.finance.yahoo.com and www.investing.com. The data was then used in the calculation of abnormal return and trading volume activity. The data analysis technique used was non-parametric paired samples difference test (Wilcoxon Signed Rank Test) for 250 days estimation period and varying window period for the Corona Virus Disease 2019 (COVID-19) event test of $(-5,5),(-15,15),(-30,30)$, and $(-$ $60,60)$. Some of the variables used in this research are listed below.

\section{Actual Return}

Return gained from changes in daily stock price. The return calculated from the difference in period $t$ stock prices and last period $\mathrm{t}-1$ stock prices, divided by period $\mathrm{t}-1$ stock prices,

Note:

$$
R_{i t}=\frac{R_{t}-R_{(t-1)}}{R_{(t-1)}} \times 100
$$

$R_{i t} \quad=$ Actual return of stock $\mathrm{i}$ in period $\mathrm{t}$

$R_{t} \quad=$ Stock price in period $\mathrm{t}$

$R_{(t-1)}=$ Stock price in period $\mathrm{t}-1$ 
Table 1. Stock Period and Index

\begin{tabular}{cccccc}
\hline Country & Indonesia & China & United Kingdom & United States & Brazil \\
\hline Index & IDX Property & SZSE Real Estate & $\begin{array}{c}\text { FTSE 350 Real } \\
\text { Estate }\end{array}$ & $\begin{array}{c}\text { S\&P 500 Real } \\
\text { Estate }\end{array}$ & $\begin{array}{c}\text { Bovespa Real } \\
\text { Estate }\end{array}$ \\
\hline Index Code & JKPROP & SZREI & FTUB8600 & SPLRCREC & IMOB \\
\hline $\mathrm{t}$-250 & 06 Mar 2019 & 01 Mar 2019 & 15 Mar 2019 & 13 Mar 2019 & 11 Mar 2019 \\
$\mathrm{t}-60$ & 12 Dec 2019 & 09 Dec 2019 & 13 Dec 2019 & 12 Dec 2019 & 10 Dec 2019 \\
$\mathrm{t}$-30 & 29 Jan 2020 & 21 Jan 2020 & 29 Jan 2020 & 28 Jan 2020 & 27 Jan 2020 \\
$\mathrm{t}-15$ & 19 Feb 2020 & 19 Feb 2020 & 19 Feb 2020 & 19 Feb 2020 & 17 Feb 2020 \\
$\mathrm{t}+0$ & 11 Mar 2020 & 11 Mar 2020 & 11 Mar 2020 & 11 Mar 2020 & 11 Mar 2020 \\
$\mathrm{t}-5$ & 04 Mar 2020 & 04 Mar 2020 & 04 Mar 2020 & 04 Mar 2020 & 04 Mar 2020 \\
$\mathrm{t}+5$ & 18 Mar 2020 & 18 Mar 2020 & 18 Mar 2020 & 18 Mar 2020 & 18 Mar 2020 \\
$\mathrm{t}+$ +15 & 02 April 2020 & 01 April 2020 & 01 April 2020 & 01 April 2020 & 01 April 2020 \\
$\mathrm{t}+$ 30 & 24 April 2020 & 23 April 2020 & 24 April 2020 & 23 April 2020 & 24 April 2020 \\
$\mathrm{t}+60$ & 16 June 2020 & 09 June 2020 & 09 June 2020 & 05 June 2020 & 08 June 2020 \\
\hline
\end{tabular}

2. Return Market

Return gained from changes in the daily stock price index. The return calculated from the difference in period $t$ stock price index and period $\mathrm{t}-1$ stock price index, divided by period $\mathrm{t}-1$ stock prices index.

$$
R_{m}=\frac{R_{m t}-R_{m(t-1)}}{R_{m(t-1)}} x 100
$$

Note:

$R_{m} \quad=$ Return of market

$R_{m t} \quad=$ Market index price in period $\mathrm{t}$

$\left.R_{m(t-1}\right)=$ Market index price in period $\mathrm{t}-1$

3. Expected Return

The return expected by investors to be gained in the future. By using the return model market method, this model is done by combining stock return with the existing market return and using a simple linear regression model.

Note:

$$
E\left(R_{i t}\right)=\alpha+\beta R_{m t}
$$

$E\left(R_{i t}\right)=$ Expected return of stock i during the test period

$\alpha \quad=$ Intercept for stock $\mathrm{i}$

$\beta \quad=$ Slope coefficient which is beta of stock i

$\mathrm{R}_{\mathrm{mt}} \quad=$ Return of the market during the test period

4. Abnormal Return

Difference between actual return and expected return.

Note:

$$
\mathrm{AR}_{\mathrm{it}}=R_{i t}-E\left(R_{i t}\right)
$$

$\mathrm{AR}_{\mathrm{it}}=$ Abnormal return of stock $\mathrm{i}$ in period $\mathrm{t}$

$R_{i t}=$ Actual return of stock $i$ in period $t$

$E\left(R_{i t}\right)=$ Expected return of stock $i$ in $t$
5. Trading Volume Activity

Comparison of the number of shares traded with the number of shares in circulation.

TVA $_{i t}=\frac{\sum \text { stock transaction volume } i \text { in period } t}{\sum \text { sum of stock } i \text { in circulation in period } t}$

Note:

$\mathrm{TVA}_{i t}=$ Trading volume activity of stock $i$ and period $\mathrm{t}$

\section{Results}

This study focuses on the announcement of COVID-19 as a pandemic by World Health Organization (WHO) on March 11, 2020, and uses the property sector index data in Indonesia (IDX Property), the United States (S\&P 500 Real Estate), Brazil (Bovespa Real Estate), China (SZSE Real Estate), and the United Kingdom (FTSE 350 Real Estate) with varying window period and estimate period of -250 , resulting in significant differences in window periods of $(-5$, $5),(-15,15),(-30,30)$ and $(-60,60)$ before and after the event date. Table 1 shows the stock period and index in the countries studied.

Based on the observation period decided, the calculation of abnormal return and trading volume of property sector stocks is shown in Table 2 and 3 which includes minimum value, maximum value, and mean value of the abnormal return.

Table 2 shows that China has a positive mean value of abnormal return before COVID-19 was announced as a pandemic in the periods of ($30,30),(-15,15)$, and $(-5,5)$ and after the announcement in the period of $(-15,15)$ it still held the positive abnormal return. On the other hand, other countries both before and after the announcement showed a negative mean abnormal return value in all periods. 
Table 2. Descriptive Statistic of Abnormal Return of Stocks in the Property Sector in 5 Countries

\begin{tabular}{|c|c|c|c|c|c|c|}
\hline $\mathrm{N}$ & Country & \multicolumn{2}{|c|}{ Period } & Mean & Min & Max \\
\hline 60 & \multirow{8}{*}{ Indonesia } & \multirow{2}{*}{$(-60,60)$} & Before & -0.1153 & -0.39 & 0.01 \\
\hline 60 & & & After & -0.1032 & -0.35 & 0.32 \\
\hline 30 & & \multirow{2}{*}{$(-30,30)$} & Before & -0.0758 & -0.44 & 0.1 \\
\hline 30 & & & After & -0.0981 & -0.38 & 0.5 \\
\hline 15 & & \multirow{2}{*}{$(-15,15)$} & Before & -0.1004 & -0.4 & 0.08 \\
\hline 15 & & & After & -0.1087 & -0.35 & 0.43 \\
\hline 5 & & \multirow{2}{*}{$(-5,5)$} & Before & -0.1305 & -0.4 & 0.05 \\
\hline 5 & & & After & -0.1974 & -0.35 & -0.08 \\
\hline 60 & \multirow{8}{*}{ China } & \multirow{2}{*}{$(-60,60)$} & Before & -0.0513 & -3.07 & 5.12 \\
\hline 60 & & & After & -0.0393 & -2.26 & 2.23 \\
\hline 30 & & \multirow{2}{*}{$(-30,30)$} & Before & 0.0092 & -3.04 & 5.09 \\
\hline 30 & & & After & -0.0116 & -2.25 & 2.26 \\
\hline 15 & & \multirow{2}{*}{$(-15,15)$} & Before & 0.1798 & -3.04 & 5.13 \\
\hline 15 & & & After & 0.1761 & -2.23 & 2.25 \\
\hline 5 & & \multirow{2}{*}{$(-5,5)$} & Before & 0.1890 & -2.03 & 4.04 \\
\hline 5 & & & After & -0.2841 & -2.00 & 0.92 \\
\hline 60 & \multirow{8}{*}{$\begin{array}{l}\text { United } \\
\text { Kingdom }\end{array}$} & \multirow{2}{*}{$(-60,60)$} & Before & -0.0116 & -2.21 & 3.03 \\
\hline 60 & & & After & -0.1828 & -4.84 & 4.92 \\
\hline 30 & & \multirow{2}{*}{$(-30,30)$} & Before & -0.0206 & -1.83 & 2.33 \\
\hline 30 & & & After & -0.3728 & -4.61 & 4.82 \\
\hline 15 & & \multirow{2}{*}{$(-15,15)$} & Before & -0.2255 & -1.94 & 2.2 \\
\hline 15 & & & After & -0.9309 & -4.68 & 4.85 \\
\hline 5 & & \multirow{2}{*}{$(-5,5)$} & Before & -0.028 & -0.68 & 1.19 \\
\hline 5 & & & After & -2.5917 & -4.66 & -0.94 \\
\hline 60 & \multirow{8}{*}{ United States } & \multirow{2}{*}{$(-60,60)$} & Before & -0.0436 & -3.93 & 3.09 \\
\hline 60 & & & After & -0.024 & -11.47 & 5.95 \\
\hline 30 & & \multirow{2}{*}{$(-30,30)$} & Before & -0.0534 & -4.11 & 3.17 \\
\hline 30 & & & After & -0.1695 & -11.74 & 6.00 \\
\hline 15 & & \multirow{2}{*}{$(-15,15)$} & Before & -0.2939 & -4.00 & 3.08 \\
\hline 15 & & & After & -0.8536 & -11.55 & 5.15 \\
\hline 5 & & \multirow{2}{*}{$(-5,5)$} & Before & -0.1665 & -3.98 & 2.9 \\
\hline 5 & & & After & -2.4884 & -11.54 & 4.71 \\
\hline 60 & \multirow{8}{*}{ Brazil } & \multirow{2}{*}{$(-60,60)$} & Before & -0.0041 & -3.27 & 2.15 \\
\hline 60 & & & After & -0.3237 & -2.01 & 9.03 \\
\hline 30 & & \multirow{2}{*}{$(-30,30)$} & Before & -0.3323 & -3.44 & 1.35 \\
\hline 30 & & & After & -0.7149 & -8.26 & 9.04 \\
\hline 15 & & \multirow{2}{*}{$(-15,15)$} & Before & -0.2493 & -3.24 & 1.26 \\
\hline 15 & & & After & -1.3478 & -7.93 & 9.00 \\
\hline 5 & & ( & Before & -0.4584 & -3.2 & 1.25 \\
\hline 5 & & $(-5,3)$ & After & -4.3822 & -7.85 & -2.33 \\
\hline
\end{tabular}

Table 3 shows the mean value of trading volume activity before the Corona Virus Disease 2019 (COVID-19) announcement as a pandemic was lower compared to after the event, except in the stock market in China and Indonesia with the window period $(-5,5)$. This shows that the announcement of Corona Virus Disease 2019 (COVID-19) as a pandemic caused an increase in the transaction volume of the stock markets in the countries studied.
Figure 1 shows the movement of abnormal return before the pandemic in blue lines, and after the pandemic in red lines. Before the event, the property index fluctuates in the countries studied though it tends to be stable, in response to the outbreak in Wuhan, China in the beginning of December 2019. After the pandemic announcement by World Health Organization (WHO), however, the index moved more aggressively to respond the announcement. 
Table 3. Descriptive Statistic of Trading Volume Activity of Stocks in the Property Sector in 5 (five) Countries

\begin{tabular}{|c|c|c|c|c|c|c|}
\hline $\mathrm{N}$ & Country & & & Mean & Min & Max \\
\hline 60 & \multirow{8}{*}{ Indonesia } & \multirow{2}{*}{$(-60,60)$} & Before & 0.0006738 & 0.00042 & 0.00112 \\
\hline 60 & & & After & 0.001694 & 0.00028 & 0.00404 \\
\hline 30 & & \multirow{2}{*}{$(-30,30)$} & Before & 0.0006214 & 0.00042 & 0.00093 \\
\hline 30 & & & After & 0.0009916 & 0.00028 & 0.00282 \\
\hline 15 & & \multirow{2}{*}{$(-15,15)$} & Before & 0.0006498 & 0.00045 & 0.00081 \\
\hline 15 & & & After & 0.0006799 & 0.00028 & 0.00155 \\
\hline 5 & & \multirow{2}{*}{$(-5,5)$} & Before & 0.0006377 & 0.00045 & 0.00081 \\
\hline 5 & & & After & 0.0005517 & 0.00031 & 0.0008 \\
\hline 60 & \multirow{8}{*}{ China } & \multirow[b]{2}{*}{$(-60,60)$} & Before & 0.007397 & 0.00396 & 0.01578 \\
\hline 60 & & & After & 0.0048616 & 0.00306 & 0.00866 \\
\hline 30 & & \multirow{2}{*}{$(-30,30)$} & Before & 0.0090359 & 0.00424 & 0.01578 \\
\hline 30 & & & After & 0.0050356 & 0.00306 & 0.00867 \\
\hline 15 & & \multirow{2}{*}{$(-15,15)$} & Before & 0.0112995 & 0.00789 & 0.01578 \\
\hline 15 & & & After & 0.0061142 & 0.0042 & 0.00867 \\
\hline 5 & & \multirow{2}{*}{$(-5,5)$} & Before & 0.0110536 & 0.00789 & 0.01423 \\
\hline 5 & & & After & 0.0068712 & 0.00584 & 0.00776 \\
\hline 60 & \multirow{8}{*}{$\begin{array}{l}\text { United } \\
\text { Kingdom }\end{array}$} & \multirow{2}{*}{$(-60,60)$} & Before & 0.0024738 & 0.00044 & 0.00756 \\
\hline 60 & & & After & 0.0061262 & 0.00246 & 0.1328 \\
\hline 30 & & \multirow{2}{*}{$(-30,30)$} & Before & 0.0028369 & 0.00108 & 0.00756 \\
\hline 30 & & & After & 0.0072092 & 0.00261 & 0.01328 \\
\hline 15 & & \multirow{2}{*}{$(-15,15)$} & Before & 0.0040294 & 0.00132 & 0.00756 \\
\hline 15 & & & After & 0.0080994 & 0.00615 & 0.1328 \\
\hline 5 & & \multirow{2}{*}{$(-5,5)$} & Before & 0.0060838 & 0.00228 & 0.00756 \\
\hline 5 & & & After & 0.0085428 & 0.00621 & 0.008542 \\
\hline 60 & \multirow{8}{*}{ United States } & \multirow{2}{*}{$(-60,60)$} & Before & 0.0069957 & 0.00149 & 0.01629 \\
\hline 60 & & & After & 0.0117077 & 0.00747 & 0.02093 \\
\hline 30 & & \multirow{2}{*}{$(-30,30)$} & Before & 0.0081025 & 0.00447 & 0.01629 \\
\hline 30 & & & After & 0.0125435 & 0.00751 & 0.01899 \\
\hline 15 & & \multirow{2}{*}{$(-15,15)$} & Before & 0.0100963 & 0.00654 & 0.01629 \\
\hline 15 & & & After & 0.0151501 & 0.01154 & 0.01899 \\
\hline 5 & & \multirow{2}{*}{$(-5,5)$} & Before & 0.0104360 & 0.00889 & 0.01204 \\
\hline 5 & & & After & 0.0166928 & 0.01535 & 0.0173 \\
\hline 60 & \multirow{8}{*}{ Brazil } & \multirow{2}{*}{$(-60,60)$} & Before & 0.0105438 & 0.00604 & 0.01843 \\
\hline 60 & & & After & 0.0152327 & 0.00783 & 0.02381 \\
\hline 30 & & \multirow{2}{*}{$(-30,30)$} & Before & 0.0113967 & 0.00604 & 0.01843 \\
\hline 30 & & & After & 0.0160086 & 0.01106 & 0.02381 \\
\hline 15 & & \multirow{2}{*}{$(-15,15)$} & Before & 0.0122845 & 0.00604 & 0.01843 \\
\hline 15 & & & After & 0.0173399 & 0.01153 & 0.02381 \\
\hline 5 & & \multirow{2}{*}{$(-5,5)$} & Before & 0.0151611 & 0.00926 & 0.01843 \\
\hline 5 & & & After & 0.0180142 & 0.01318 & 0.02216 \\
\hline
\end{tabular}
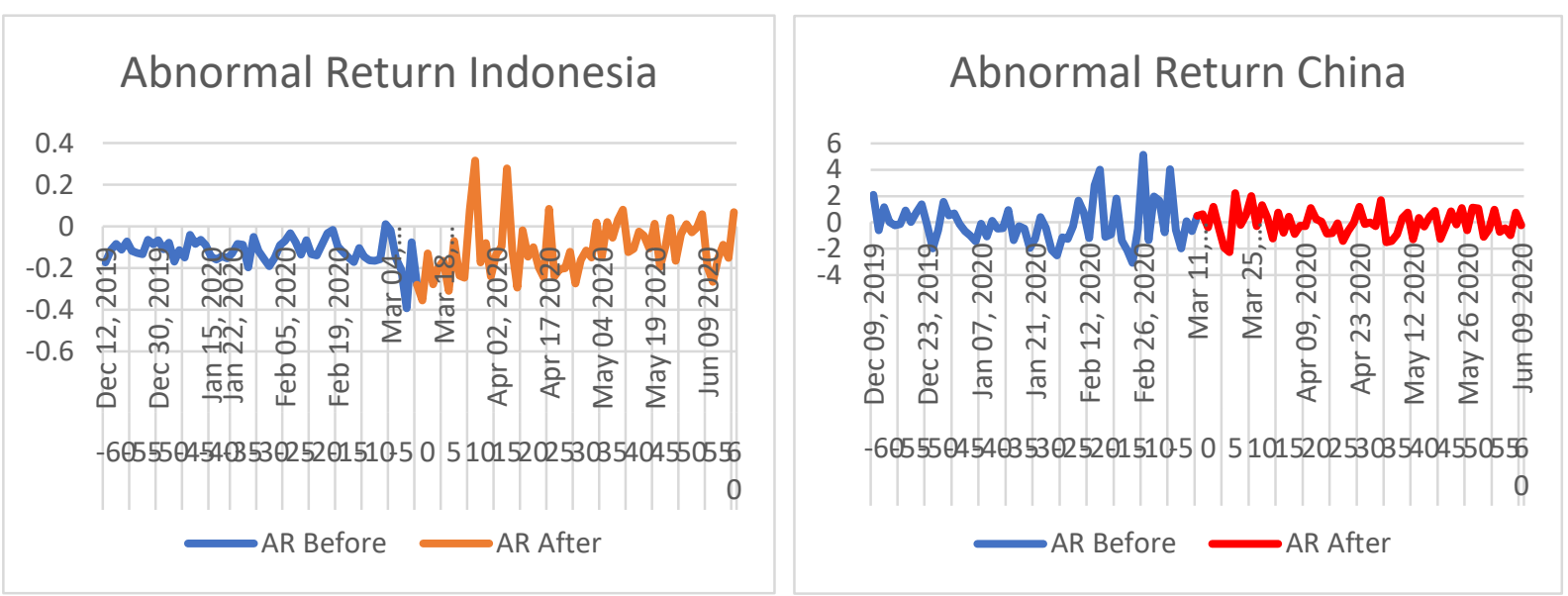

Figure 1. (a) Abnormal Return Movements of Indonesia and China 

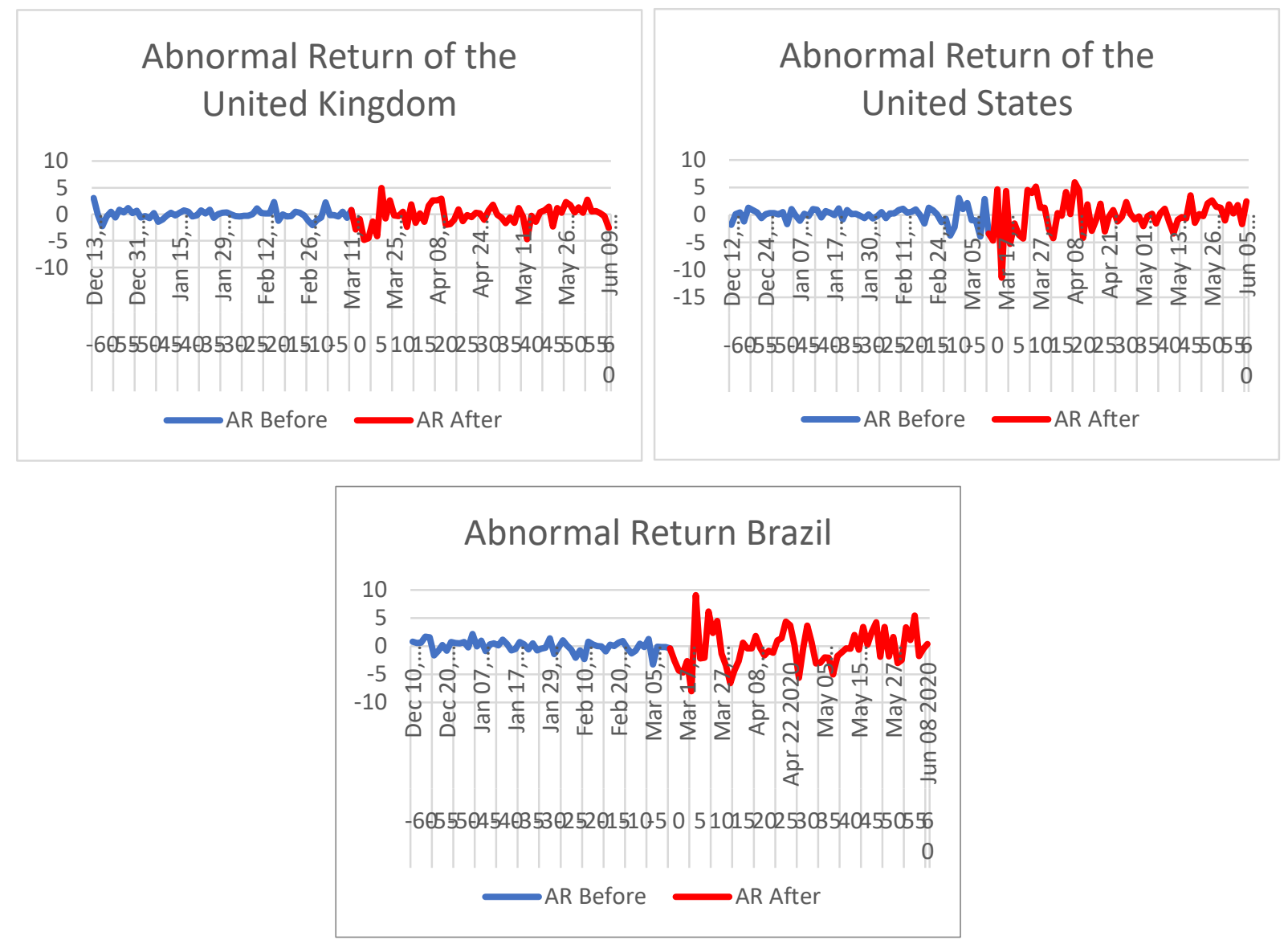

Figure 1. (b) Abnormal Return Movements of United Kingdom, United States, and Brazil

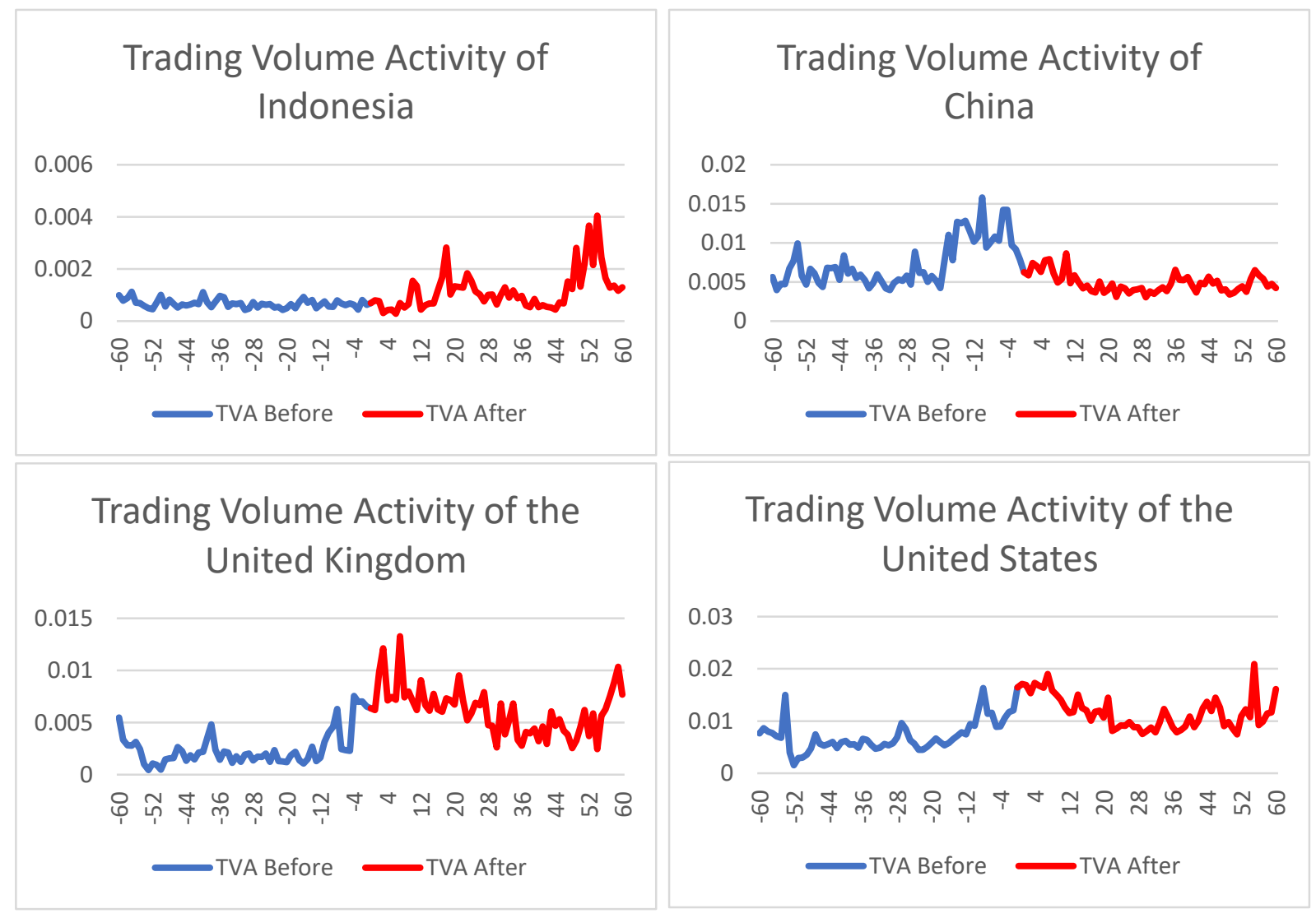

Figure 2. (a) Trading Volume Activity Movements of Indonesia, China, United Kingdom, and United States 


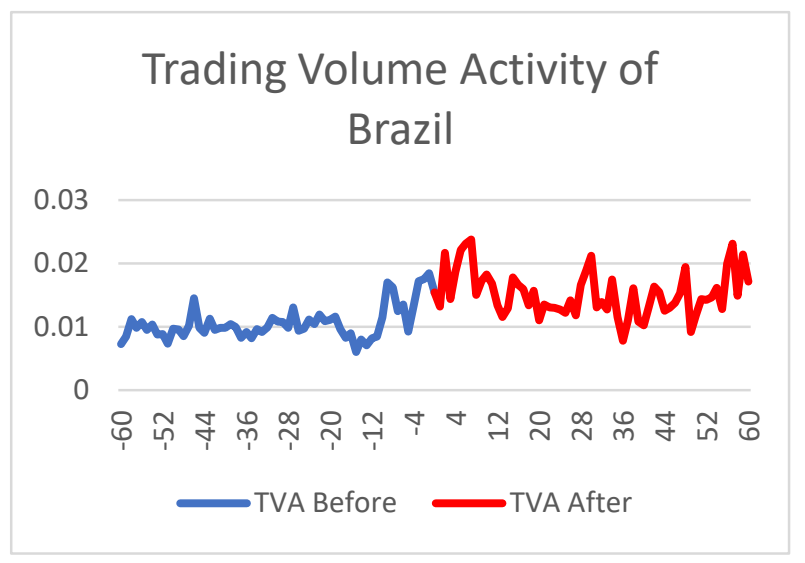

Figure 2. (b) Trading Volume Activity Movements of Brazil

Figure 2 shows that the trading volume activity before and after the event showed a difference, where the trading movements before the announcement were more fluctuating and became more aggressive after the announcement. Data analysis includes the abnormal return of property stock index in Indonesia, China, the United Kingdom, the United States, and Brazil before and after the announcement of Corona Virus Disease 2019 (COVID-19) as a pandemic used window period of $(-60,60),(-30,30),(-15,15)$ and $(-5,5)$. The difference test used a pair of nonparametric samples (Wilcoxon) to see the event difference.

Table 4. Results of Abnormal Return Test

\begin{tabular}{clcc}
\hline No & Country (Window Period) & $\begin{array}{c}\text { Wilcoxon } \\
\text { Signed } \\
\text { Rank } \\
\text { Test }\end{array}$ & Details \\
\hline 1 & Indonesia (-60,60) & 0.643 & Accept $\mathrm{H}_{0}$ \\
& Indonesia (-30,30) & 0.171 & Accept $\mathrm{H}_{0}$ \\
& Indonesia (-15,15) & 0.65 & Accept $\mathrm{H}_{0}$ \\
& Indonesia (-5,5) & 0.5 & Accept $\mathrm{H}_{0}$ \\
\hline 2 & China (-60,60) & 0.653 & Accept $\mathrm{H}_{0}$ \\
& China (-30,30) & 0.766 & Accept $\mathrm{H}_{0}$ \\
& China (-15,15) & 0.65 & Accept $\mathrm{H}_{0}$ \\
& China (-5,5) & 0.5 & Accept $\mathrm{H}_{0}$ \\
\hline 3 & United Kingdom (-60,60) & 0.746 & Accept $\mathrm{H}_{0}$ \\
& United Kingdom (-30,30) & 0.289 & Accept $\mathrm{H}_{0}$ \\
& United Kingdom (-15,15) & 0.256 & Accept $\mathrm{H}_{0}$ \\
& United Kingdom (-5,5) & 0.043 & Reject $\mathrm{H}_{0}$ \\
\hline 4 & United States (-60,60) & 0.877 & Accept $\mathrm{H}_{0}$ \\
& United States (-30,30) & 0.959 & Accept $\mathrm{H}_{0}$ \\
& United States (-15,15) & 0.91 & Accept $\mathrm{H}_{0}$ \\
& United States (-5,5) & 0.5 & Accept $\mathrm{H}_{0}$ \\
\hline 5 & Brazil (-60,60) & 0.282 & Accept $\mathrm{H}_{0}$ \\
& Brazil (-30,30) & 0.349 & Accept $\mathrm{H}_{0}$ \\
& Brazil (-15,15) & 0.307 & Accept $\mathrm{H}_{0}$ \\
& Brazil (-5,5) & 0.043 & Reject $\mathrm{H}_{0}$ \\
\hline \multirow{2}{*}{} & &
\end{tabular}

The test results shown in Table 4 showed that there is not a significant difference between the abnormal return before and after the event, except in the United Kingdom with the window period of $(-5,5)$ and with the window period Brazil $(-5,5)$. Table 5 proved that there is a significant difference in the variable of trading volume activity before and after the event, except in Indonesia in the window periods of $(-15,15)$, $(-5,5)$ and Brazil in the period of $(-5,5)$.

Table 5. Results of Trading Volume Activity Difference Test

\begin{tabular}{|c|c|c|c|}
\hline No & Country (Period) & $\begin{array}{c}\text { Wilcoxon } \\
\text { Signed } \\
\text { Rank Test }\end{array}$ & Details \\
\hline \multirow[t]{4}{*}{1} & Indonesia $(-60,60)$ & 0.001 & Reject $\mathrm{H}_{0}$ \\
\hline & Indonesia $(-30,30)$ & 0.001 & Reject $\mathrm{H}_{0}$ \\
\hline & Indonesia $(-15,15)$ & 0.532 & Accept $\mathrm{H}_{0}$ \\
\hline & Indonesia $(-5,5)$ & 0.345 & Accept $\mathrm{H}_{0}$ \\
\hline \multirow[t]{4}{*}{2} & China $(-60,60)$ & 0.001 & Reject $\mathrm{H}_{0}$ \\
\hline & China $(-30,30)$ & 0.001 & Reject $\mathrm{H}_{0}$ \\
\hline & China $(-15,15)$ & 0.001 & Reject $\mathrm{H}_{0}$ \\
\hline & China $(-5,5)$ & 0.043 & Reject $\mathrm{H}_{0}$ \\
\hline \multirow[t]{4}{*}{3} & $\begin{array}{l}\text { United Kingdom } \\
(-60,60)\end{array}$ & 0.001 & Reject $\mathrm{H}_{0}$ \\
\hline & $\begin{array}{l}\text { United Kingdom } \\
(-30,30)\end{array}$ & 0.001 & Reject $\mathrm{H}_{0}$ \\
\hline & $\begin{array}{l}\text { United Kingdom } \\
(-15,15)\end{array}$ & 0.001 & Reject $\mathrm{H}_{0}$ \\
\hline & $\begin{array}{l}\text { United Kingdom } \\
(-5,5)\end{array}$ & 0.043 & Reject $\mathrm{H}_{0}$ \\
\hline \multirow[t]{4}{*}{4} & $\begin{array}{l}\text { United States } \\
(-60,60)\end{array}$ & 0.001 & Reject $\mathrm{H}_{0}$ \\
\hline & $\begin{array}{l}\text { United States } \\
(-30,30)\end{array}$ & 0.001 & Reject $\mathrm{H}_{0}$ \\
\hline & $\begin{array}{l}\text { United States } \\
(-15,15)\end{array}$ & 0.001 & Reject $\mathrm{H}_{0}$ \\
\hline & $\begin{array}{l}\text { United States } \\
(-5,5)\end{array}$ & 0.043 & Reject $\mathrm{H}_{0}$ \\
\hline \multirow[t]{4}{*}{5} & Brazil $(-60,60)$ & 0.001 & Reject $\mathrm{H}_{0}$ \\
\hline & Brazil $(-30,30)$ & 0.001 & Reject $\mathrm{H}_{0}$ \\
\hline & Brazil $(-15,15)$ & 0.012 & Reject $\mathrm{H}_{0}$ \\
\hline & Brazil $(-5,5)$ & 0.138 & Accept $\mathrm{H}_{0}$ \\
\hline
\end{tabular}




\section{Discussion}

From when the Corona Virus Disease 2019 (COVID-19) virus was first discovered in Wuhan, China in the beginning of December 2019 until the pandemic announcement by World Health Organization (WHO), the stock market in several countries have responded to the event, which means the market reacted before the announcement of the spread of Corona Virus Disease 2019 (COVID-19) as a pandemic by World Health Organization (WHO) on March $11^{\text {th }}, 2020$. Therefore, as proven by this study, there is not a significant difference between before and after the event. This also agrees with Ashraf (2020), who stated that the stock market acted preemptively in the early days when the Corona Virus Disease 2019 (COVID-19) cases were first discovered in Wuhan, China. The announcement made by World Health Organization (WHO) was bad news that negatively affected stock prices, which occurred to the Hang Seng Index and Shanghai Exchange Composite Index (Al-Awadhi, Alsaifia, AlAwadhi, \& Alhammadi, 2020), the accumulating death counts caused by Corona Virus Disease 2019 (COVID-19) (Baek, Mohanty, \& Glambosky, 2020), along with the lockdown policies enforced by countries and the daily new cases of Corona Virus Disease 2019 (COVID-19) (Anh \& Gan, 2020) ground the economic activities to a complete halt (Mazur, Dang, \& Vega, 2020).

The Corona Virus Disease 2019 (COVID19) pandemic has significantly impacted the stock markets of many countries. To name a few, Mauritius has its stock market performance decrease by about $21 \%$ due to the COVID-19, followed by Morocco (17\%), Kenya (15\%), Nigeria (13\%), Tanzania (11\%), Tunisia $(9.1 \%)$, Ghana (6.5 \%), and Zambia (3.6 \%), and Botswana with the least $(2.7 \%)$ (Takyi \& Bentum-Ennin, 2020). The increase in trading volume activity after the event was caused by investors that responded negatively who sold their stocks and switched to other investment instruments, causing the trading volume activity to rise. This was also expressed by Nia (2020), that investors tend to choose to invest in safe heaven investment instruments during the pandemic period. We documented intensified share trading activities around the world during the Corona Virus Disease 2019 (COVID-19) pandemic period (Mardy \& Angel, 2020). The window period used in this research are $(-5,5)$,
$(-15,15),(-30,30)$ and $(-60,60)$. Its aim is to figure out how sensitive the window period is in the country under this research. The case in Indonesia occurred more sensitively in more extended periods of $(-30,30)$ and $(-60,60)$ which was proven significantly different before and after the event. The cases in China, the United Kingdom, the United States, and Brazil are sensitive in short and long periods in terms of the trading volume activity. This reflects the more efficient stock market of China, the United Kingdom, the United States, and Brazil when compared to Indonesia for responding to an event quickly for an extended period. The quicker a market responds to an information, the more efficient it is (Tandelilin, 2010). Despite the findings, this study also has some limitations. First, this study only covered a brief time period. Future studies may look at the longer long-term effect of Corona Virus Disease 2019 (COVID-19) on capital markets over a period of a decade or more. Second, this study only examines the World Health Organization's announcement of the pandemic. Since there is a risk of multiple incidents or other harmful events during the event duration, the findings of discrepancies before and after the event are based on the impact of the observed event, which is the World Health Organization's (WHO) declaration of a pandemic.

Future studies may use this study to examine other significant events, both economic and political, as well as events that have never occurred before. Third, this research was carried out in a small number of countries. More research is expected to be able to cover a larger area of the region. This study also offers some advice to investors, such as the importance of being vigilant and not rushing decisions in the face of such events. The appearance of a problem or event does not always correspond to anticipated investor expectations or facts. Furthermore, since the stock price has been corrected, this event can provide an incentive for investors to invest.

\section{Conclusion}

The study of property index in five countries namely Indonesia (IDX Property), China (SZSE Real Estate), the United Kingdom (FTSE 350 Real Estate), the United States (S\&P 500 Real Estate), and Brazil (Bovespa Real Estate) towards the Corona Virus Disease 2019 (COVID-19) announcement as a pandemic by World Health Organization (WHO) showed no significant difference in the variable of abnormal return 
before and after the event, except for the United Kingdom with the window period of $(-5,5)$ and Brazil with the same window period of $(-5,5)$. This was caused by the market having reacted in advance before the announcement in response to the early cases of the Corona Virus Disease 2019 (COVID-19) spread. The trading volume activity experienced a significant increase after the event, which means that the market reacted to the event.

The test result of the variable of trading volume activity showed a significant difference before and after the event, with the majority in the extended period. With varying window period, it can be conclusion can be drawn that the sensitivity of the stock market of each country studied is different, the market in Indonesia is sensitive in the extended period, while the market in the United States, Brazil, China, and the United Kingdom are more sensitive in the short and long period. This study is expected to give an insight to stock investors to look for information and process it regarding the market characteristic of each country to avoid loss when making stock investment decisions in said country. Moreover, to help the stock market get through this pandemic and the slumped economic condition in almost every nation, governments also need to issue policies that help the property sector in particular and other sectors in general in order to recover immediately.

\section{References}

AlAli, M. S. (2020). The Effect of WHO COVID19 Announcement on Asian Stock Markets Returns: An Event Study Analysis. Journal of Economics and Business, 3(3), 1051-1054.

Al-Awadhi, A. M., Alsaifia, K., Al-Awadhi, A., \& Alhammadi, S. (2020). Death and Contagious Infectious Diseases: Impact of The COVID-19 Virus on Stock Market Returns. Journal of Behavioral and Experimental Finance, 27(April 2020), 1-5. doi:10.1016/j. jbef.2020.100326

Anh, D. T., \& Gan, C. (2020). The Impact of The COVID-19 Lockdown on Stock Market Performance: Evidence from Vietnam. Journal of Economic Studies. doi:10.1108/ JES-06-2020-0312

Ashraf, B. N. (2020). Stock Markets' Reaction to COVID-19: Cases or Fatalities? Research in International Business and Finance, 54(Dec 2020), 1-18.doi:10.1016/j.ribaf.2020.101249

Baek, S., Mohanty, S., \& Glambosky, M. (2020). COVID-19 and Stock Market Volatility: An Industry Level Analysis. Finance Research
Letters, 37(November 2020). doi:10.1016/j.frl. 2020.101748

Bash, A. (2020). International Evidence of COVID-19 and Stock Market Returns: An Event Study Analysis. International Journal of Economics and Financial Issues, 10(4), 34-38. doi:10.32479/ijefi.9941

Chen, A. H., \& Siems, T. F. (2004). The Effects of Terrorism on Global Capital Markets. European Journal of Political Economy, 20 (2), 349-366. doi: 10.1016/j.ejpoleco.2003. 12.005

Chen, M. H., Jang, S. C., \& Kim, W. G. (2007). The Impact of The SARS Outbreak on Taiwanese Hotel Stock Performance: An Event Study Approach. International Journal of Hospitality Management, 26(1), 200-212. doi:10.1016/j.ijhm.2005.11.004

Dunford, D., Dale, B., Stylianou, N., Lowther, E., Ahmed, M., \& Arenas, I. (2020). Coronavirus: The World in Lockdown in Maps and Charts. Retrieved from BBC News: www.bbc.com/ news/world-52103747

Fama, E. F. (1970). Efficient Capital Markets: A Review of Theory and Empirical Work. The Journal of Finance, 25(2), 383-417. doi: $10.2307 / 2325486$

Goodell, J. (2020). COVID-19 and Finance : Agendas for Future Research. Finance Research Letters.

Guidolin, M., \& Ferrara, E. L. (2010). The Economic Effects of Violent Conflict: Evidence from Asset Market Reactions. Journal of Peace Research, 47(6), 671-684. Retrieved from https://www.jstor.org/stable/20798955

Hartono, J. (2015). Studi Peristiwa: Menguji Reaksi Pasar Modal Akibat Suatu Peristiwa. Yogyakarta: BPFE.

Husnan, S. (2005). Dasar-Dasar Teori Portofolio Dan Analisis Sekuritas (4th Ed.). Yogyakarta, Indonesia: UPP AMD YKPN.

Ichev, R., \& Marinc, M. (2018). Stock Prices and Geographic Proximity of Information: Evidence from The Ebola Outbreak. International Review of Financial Analysis, 56(March 2018), 153-166. doi: 10.1016/j.irfa.2017.12. 004

Kandil Goker, I. E., Eren, B. S., \& Karaca, S. S. (2020). The Impact of The COVID-19 (Coronavirus) on The Borsa Istanbul Sector Index Returns: An Event Study. Journal of Social Sciences, 14-41.

Mardy, C., \& Angel, Z. (2020). Trading from Home: The Impact of COVID-19 on Trading 
Volume Around The World. Finance Research Letters.

Mazur, M., Dang, M., \& Vega, M. (2020). COVID-19 and The March 2020 Stock Market Crash. Evidence from S\&P1500. Finance Research Letters, 38(1), 1-8. doi:10.1016/j.frl. 2020.101690

Nia, V. M. (2020). The Effect of Corona Outbreak on The Indonesian Stock Market. American Journal of Humanities and Social Sciences Research, 4(3), 358-370.

Salim, L. (2003). Analisa Teknikal dalam Perdagangan Saham. Jakarta: PT. Elex Media Komputindo.

Samsul, M. (2006). Pasar Modal dan Manajemen Portofolio. Surabaya: Erlangga.

Setyawan, S. A. (2000). Analisis Reaksi Pasar
Modal Terhadap Kenaikan Harga BBM (Studi Kasus di Bursa Efek Jakarta untuk SahamSaham LQ 45). Thesis Universitas Diponegoro.

Sunariyah. (2011). Pengantar Pengetahuan Pasar Modal (6th Ed.). Yogyakarta, Indonesia: UPP Sekolah Tinggi Ilmu Manajemen Yayasan Keluarga Pahlawan Negara.

Takyi, P. O., \& Bentum-Ennin, I. (2020). The Impact of COVID-19 on Stock Market Performance in Africa: A Bayesian Structural Time Series Approach. Journal of Economics and Business.

Tandelilin, E. (2010). Portofolio dan Investasi: Teori Dan Aplikasi. Yogyakarta, Indonesia: Kanisius IKAPI. 